\title{
Front Matter: Volume 7416
}

, "Front Matter: Volume 7416," Proc. SPIE 7416, Organic Photovoltaics X, 741601 (19 October 2009); doi: 10.1117/12.846117

SPIE Event: SPIE Photonic Devices + Applications, 2009, San Diego, California, SPIE. United States 


\section{PROCEEDINGS OF SPIE}

\section{Organic Photovoltaics $X$}

Zakya H. Kafafi

Paul A. Lane

Editors

3-6 August 2009

San Diego, California, United States

Sponsored and Published by

SPIE

Volume 7416

Proceedings of SPIE, 0277-786X, v. 7416 
The papers included in this volume were part of the technical conference cited on the cover and title page. Papers were selected and subject to review by the editors and conference program committee. Some conference presentations may not be available for publication. The papers published in these proceedings reflect the work and thoughts of the authors and are published herein as submitted. The publisher is not responsible for the validity of the information or for any outcomes resulting from reliance thereon.

Please use the following format to cite material from this book:

Author(s), "Title of Paper," in Organic Photovoltaics X, edited by Zakya H. Kafafi, Paul A. Lane, Proceedings of SPIE Vol. 7416 (SPIE, Bellingham, WA, 2009) Article CID Number.

ISSN 0277-786X

ISBN 9780819477064

Published by

SPIE

P.O. Box 10, Bellingham, Washington 98227-0010 USA

Telephone +1 3606763290 (Pacific Time) · Fax +1 3606471445

SPIE.org

Copyright (c) 2009, Society of Photo-Optical Instrumentation Engineers

Copying of material in this book for internal or personal use, or for the internal or personal use of specific clients, beyond the fair use provisions granted by the U.S. Copyright Law is authorized by SPIE subject to payment of copying fees. The Transactional Reporting Service base fee for this volume is $\$ 18.00$ per article (or portion thereof), which should be paid directly to the Copyright Clearance Center (CCC), 222 Rosewood Drive, Danvers, MA 01923. Payment may also be made electronically through CCC Online at copyright.com. Other copying for republication, resale, advertising or promotion, or any form of systematic or multiple reproduction of any material in this book is prohibited except with permission in writing from the publisher. The CCC fee code is 0277-786X/09/\$18.00.

Printed in the United States of America.

Publication of record for individual papers is online in the SPIE Digital Library.

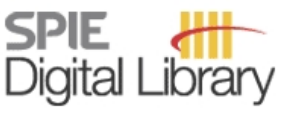

SPIEDigitalLibrary.org

Paper Numbering: Proceedings of SPIE follow an e-First publication model, with papers published first online and then in print and on CD-ROM. Papers are published as they are submitted and meet publication criteria. A unique, consistent, permanent citation identifier (CID) number is assigned to each article at the time of the first publication. Utilization of CIDs allows articles to be fully citable as soon they are published online, and connects the same identifier to all online, print, and electronic versions of the publication. SPIE uses a six-digit CID article numbering system in which:

- The first four digits correspond to the SPIE volume number.

- The last two digits indicate publication order within the volume using a Base 36 numbering system employing both numerals and letters. These two-number sets start with 00, 01, 02, 03, 04 , $05,06,07,08,09,0 A, 0 B \ldots$. OZ, followed by 10-1Z, 20-2Z, etc.

The CID number appears on each page of the manuscript. The complete citation is used on the first page, and an abbreviated version on subsequent pages. Numbers in the index correspond to the last two digits of the six-digit CID number. 


\section{Contents}

vii Conference Committee

ix WISE: the Wide-field Infrared Survey Explorer (Plenary Paper) [7419A-204]

E. L. Wright, Univ. of California, Los Angeles (United States)

NANOSTRUCTURED ORGANIC AND HYBRID SOLAR CELLS I: JOINT SESSION WITH CONFERENCE 7411

741603 Transparent conductive layers for organic solar cells: simulation and experiment [7416-69] J. Meiss, N. Allinger, C. Falkenberg, K. Leo, M. Riede, Technische Univ. Dresden (Germany)

741605 The use of nanofibers of P3HT in bulk heterojunction solar cells: the effect of order and morphology on the performance of P3HT:PCBM blends [7416-02]

D. J. M. Vanderzande, Univ. Hasselt (Belgium) and IMEC (Belgium); W. D. Oosterbaan, Univ. Hasselt (Belgium); V. Vrindts, IMEC (Belgium); S. Bertho, J. C. Bolsée, A. Gadisa, K. Vandewal, Univ. Hasselt (Belgium); J. Manca, Univ. Hasselt (Belgium) and IMEC (Belgium); L. Lutsen, IMEC (Belgium); T. J. Cleij, J. D'Haen, Univ. Hasselt (Belgium); J. Zhao, G. Van Assche, B. Van Mele, Vrije Univ. Brussel (Belgium)

NANOSTRUCTURED ORGANIC AND HYBRID SOLAR CELLS II: JOINT SESSION WITH CONFERENCE 7411

$741607 \quad$ Hybrid solar cells using ZnO nanorods [7416-04]

A. Vasudevan, S. Jung, T. Ji, Univ. of Arkansas (United States)

NOVEL DONORS AND ACCEPTORS FOR ORGANIC PHOTOVOLTAICS

$74160 \mathrm{~A}$ Dendrimers for photon harvesting in organic and organic/inorganic hybrid solar cells [7416-07]

B.-K. An, B. Langley, P. Burn, P. Meredith, The Univ. of Queensland (Australia)

\section{TOWARD THE COMMERCIALIZATION OF ORGANIC SOLAR CELLS}

$7416 \mathrm{OH} \quad$ Degradation and stability of R2R manufactured polymer solar cells [7416-73]

K. Norrman, F. C. Krebs, Technical Univ. of Denmark (Denmark)

7416 OK Efficient and long-term stable organic vacuum deposited tandem solar cells [7416-17]

G. Schwartz, B. Maennig, C. Uhrich, W. Gnehr, S. Sonntag, O. Erfurth, E. Wollrab, K. Walzer, M. Pfeiffer, heliatek GmbH (Germany) 
STABILITY AND DEGRADATION PROCESSES IN ORGANIC SOLAR CELLS: JOINT SESSION WITH CONFERENCE 7412

741600 Real time measurement of the structural change in P3HT:PCBM thin films and the relation with device performance in OPV cells [7416-21]

H. J. Kim, Seoul National Univ. (Korea, Republic of); H. H. Lee, Pohang Accelerator Lab.

(Korea, Republic of); J.-J. Kim, Seoul National Univ. (Korea, Republic of)

\section{BULK HETEROJUNCTION SOLAR CELLS: PERFORMANCE AND MORPHOLOGY}

7416 OP High efficiency polymer solar cells with internal quantum efficiency approaching $100 \%$ (Invited Paper) [7416-22]

S. H. Park, Univ. of California, Santa Barbara (United States) and Gwangju Institute of Science and Technology (Korea, Republic of); M. Leclerc, Univ. Laval (Canada);

A. J. Heeger, K. Lee, Univ. of California, Santa Barbara (United States) and Gwangju Institute of Science and Technology (Korea, Republic of)

$74160 Q \quad B u l k$ vs. surface recombination in polymer-fullerene solar cells [7416-23]

C. Deibel, T. Strobel, A. Wagenpfahl, M. Limpinsel, M. Mingebach, Julius-Maximilians-Univ. of Würzburg (Germany); V. Dyakonov, Julius-Maximilians-Univ. of Würzburg (Germany) and Bavarian Ctr. for Applied Energy Research E.V. (Germany)

7416 OT Fabrication and optimization of P3HT:PCBM organic photovoltaic devices (Invited Paper) [7416-26]

J. W. Kingsley, A. Green, D. G. Lidzey, The Univ. of Sheffield (United Kingdom)

\section{HYBRID AND DYE-SENSITIZED ORGANIC SOLAR CELLS}

7416 0X Highly efficient dye-sensitized solar cells (Invited Paper) [7416-30]

L. Han, A. Islam, National Institute for Materials Science (Japan)

\section{NOVEL CONCEPTS AND STRUCTURES FOR ORGANIC SOLAR CELLS}

741611 Semi-transparent inverted organic solar cells [7416-34]

H. Schmidt, T. Winkler, M. Tilgner, H. Flügge, S. Schmale, T. Bülow, J. Meyer, H.-H. Johannes, T. Riedl, W. Kowalsky, Technische Univ. Braunschweig (Germany)

741613 Fabrication considerations in fiber-based organic photovoltaics [7416-36] W. Zhou, W. Nie, Y. Li, J. Liu, D. L. Carroll, Wake Forest Univ. (United States)

741614 Fully solution-processed organic solar cells on metal foil substrates [7416-37] W. Gaynor, J.-Y. Lee, P. Peumans, Stanford Univ. (United States) 
74161 A Effect of fabrication processes on bulk heterojunctions (BHJ) photovoltaic device performance [7416-45]

K. Y. Cheung, C. T. Yip, M. K. Fung, A. B. Djurišić, W. K. Chan, The Univ. of Hong Kong (Hong Kong, China); Z. He, X. Z. Wang, C. L. Ho, W. Y. Wong, Hong Kong Baptist Univ. (Hong Kong, China)

$74161 \mathrm{E}$ Solution processable boron subphthalocyanine derivatives as active materials for organic photovoltaics [7416-50]

B. Ma, Lawrence Berkeley National Lab. (United States); Y. Miyamoto, Lawrence Berkeley National Lab. (United States) and Univ. of California, Berkeley (United States); C. H. Woo, Univ. of California, Berkeley (United States); J. M. J. Fréchet, Lawrence Berkeley National Lab. (United States) and Univ. of California, Berkeley (United States); F. Zhang, Y. Liu, Lawrence Berkeley National Lab. (United States)

$7416 \mathrm{IF} \quad$ Flexible polymer electronic devices using highly conductive polyaniline electrode [7416-52] B. H. Lee, H. C. Back, S. H. Park, K. Lee, Gwangju Institute of Science and Technology (Korea, Republic of)

7416 1G Design and synthesis of side-chain functionalized regioregular poly(3-hexylthiophene)based copolymers and application in polymer:fullerene bulk heterojunction solar cells [7416-53]

B. Campo, W. D. Oosterbaan, Univ. Hasselt (Belgium); J. Gilot, Technische Univ. Eindhoven (Netherlands); T. J. Cleij, Univ. Hasselt (Belgium); L. Lutsen, IMEC (Belgium); R. A. J. Janssen, Technische Univ. Eindhoven (Netherlands); D. Vanderzande, Univ. Hasselt (Belgium) and IMEC (Belgium)

$7416 \mathrm{1H}$ Performance enhancement of organic/inorganic hybrid solar cells by improving the optical absorption of polymer [7416-54]

J.-S. Huang, C.-Y. Chou, M.-Y. Liu, C.-H. Wu, Y.-H. Lin, W.-H. Lin, C.-F. Lin, National Taiwan Univ. (Taiwan)

$74161 \mathrm{~J}$ Enhanced optical absorption of organic materials via surface plasmon resonance in gold nanoparticles [7416-56]

W.-C. Lai, G.-D. J. SU, National Taiwan Univ. (Taiwan)

$74161 \mathrm{~L} \quad$ Characterising dye-sensitized solar cells [7416-58]

L. L. Tobin, T. O'Reilly, D. Zerulla, J. T. Sheridan, Univ. College Dublin (Ireland)

741610 Characterization of pore-filling of spiro-MeOTAD in solid-state dye-sensitized solar cells and its consequence in device performance [7416-61]

I-K. Ding, Stanford Univ. (United States); N. Tétreault, Ecole Polytechnique Fédérale de Lausanne (Switzerland); B. E. Hardin, E. H. Smith, Stanford Univ. (United States); M. Grätzel, Ecole Polytechnique Fédérale de Lausanne (Switzerland); M. D. McGehee, Stanford Univ. (United States)

$74161 Q \quad$ Solvent effect on the morphology of P3HT/PCBM films [7416-63]

Y. Xie, P. Dutta, D. Cengher, V. Bommisetty, J. Li, D. Galipeau, Q. Qiao, South Dakota State Univ. (United States) 
7416 IW The effect of molybdenum oxide interlayer on organic photovoltaic cells [7416-70] J. Subbiah, D. Y. Kim, F. So, Univ. of Florida (United States)

741612 Carrier dynamics of composite and nanolayered films of zinc phthalocyanine and $\mathrm{C}_{60}$ measured by time-resolved terahertz spectroscopy [7416-74]

P. A. Lane, J. S. Melinger, Naval Research Lab. (United States); O. Esenturk, E. J. Heilweil, National Institute of Standards and Technology (United States)

Author Index 


\title{
Conference Committee
}

\author{
Symposium Chair
}

Zakya H. Kafafi, National Science Foundation (United States)

Conference Chair

Zakya H. Kafafi, National Science Foundation (United States)

Conference Cochairs

Christoph J. Brabec, Friedrich-Alexander-Universität Erlangen-Nürnberg

(Germany) and Bayerisches Zentrum für Angewandte

Energieforschung (Germany)

Paul A. Lane, Naval Research Laboratory (United States)

Program Committee

Katsuhiko Fujita, Kyushu University (Japan)

Rene A. Janssen, Technische Universiteit Eindhoven (Netherlands)

Bernard Kippelen, Georgia Institute of Technology (United States)

Kwanghee Lee, Gwangju Institute of Science and Technology (Korea,

Republic of)

Toby B. Meyer, Solaronix SA (Switzerland)

Peter Peumans, Stanford University (United States)

Sean E. Shaheen, University of Denver (United States)

Jiangeng Xue, University of Florida (United States)

Yang Yang, University of California, Los Angeles (United States)

Session Chairs

Photonic Materials and Devices Plenary Session

Linda Sapochak, National Science Foundation (United States)

1 Nanostructured Organic and Hybrid Solar Cells I: Joint Session with Conference 7411

Sean E. Shaheen, University of Denver (United States)

2 Nanostructured Organic and Hybrid Solar Cells II: Joint Session with Conference 7411

Dana C. Olson, National Renewable Energy Laboratory (United States) 
3 Novel Donors and Acceptors for Organic Photovoltaics

Gilles Dennler, Konarka Austria Forschungs und Entwicklungs $\mathrm{GmbH}$

(Austria)

$4 \quad$ Charge Transfer Processes and Excitons: Joint Session with Conference 7396

David G. Lidzey, The University of Sheffield (United Kingdom)

5 Toward the Commercialization of Organic Solar Cells

Linda Sapochak, National Science Foundation (United States)

6 Stability and Degradation Processes in Organic Solar Cells: Joint Session with Conference 7412

Steve Hogan, Spire Corporation (United States)

7 Bulk Heterojunction Solar Cells: Performance and Morphology

Paul A. Lane, Naval Research Laboratory (United States)

$8 \quad$ Hybrid and Dye-sensitized Organic Solar Cells

Barry P. Rand, IMEC (Belgium)

$9 \quad$ Novel Concepts and Structures for Organic Solar Cells

Brian C. O'Regan, Imperial College London (United Kingdom) 